This Journal is available at Telkom University online Journals

Jurnal Manajemen Indonesia

\title{
The Role of Service Quality on Subjective Well-Being of Students, With Mediators of Satisfaction and Customer Company Identification
}

\author{
Muhamad Singgih Pradipto ${ }^{1}$ and Albari $^{2}$ \\ 1,2 Management, Faculty of Business and Economics, Universitas Islam Indonesia, Yogyakarta
}

\begin{abstract}
The level of service quality is often a shared measure between providers and users of products for transactions. High quality demands by service users can make service providers to implement an effective work culture. For service users, quality can be used as a basis for assessing satisfaction after receiving service. Using certain services can also arouse the customer's self-perception that he is fit to consume the service produced by providers who are committed to quality. High results from quality, satisfaction, and self-identification of users at service providers become the basis for users to conduct subjective well-being evaluations from time to time. The relationship between these variables was disclosed in this study. This study used a survey method, with a population of students who were still actively studying at 6 universities in DIY. A total of 166 students were selected by convenience sampling method to serve as research samples. By using regression analysis and the SPSS program, it can be proven that there is an indirect effect of service quality on subjective well-being. The results showed that satisfaction and customer-company identification have very important roles, because both variables function as mediators of the influence of service quality on subjective well-being, but satisfaction has a more dominant role than customer identification. From the results of this study it is suggested that universities need to pay attention to the closeness of the relationship with their students, but what is more important is to increase their satisfaction with overall services, such as when they are on campus
\end{abstract}

Keywords - service quality, satisfaction, customer-company identification, subjective well-being

\begin{abstract}
Abstrak
Tingkat kualitas jasa sering kali menjadi ukuran bersama antara penyedia dan pengguna produk untuk bertransaksi. Tuntutan kualitas yang tinggi oleh pengguna jasa dapat menjadikan penyedia jasa untuk menerapkan budaya kerja yang efektif. Bagi pengguna jasa, kualitas bisa digunakan sebagai dasar untuk menilai kepuasannya setelah menerima jasa. Menggunakan jasa tertentu juga dapat membangkitkan persepsi diri pelanggan bahwa dirinya layak untuk mengonsumsi jasa yang dihasilkan oleh penyedia yang berkomitmen pada kualitas. Hasil yang tinggi dari kualitas, kepuasan, dan identifikasi diri pengguna pada penyedia jasa menjadi dasar pengguna untuk melakukan evaluasi kesejahteraan subyektif dari waktu ke waktu. Keterkaitan antar variabel tersebut diungkap dalam penelitian ini. Penelitian ini menggunakan metode survei, dengan populasi mahasiswa yang masih aktif kuliah di 6 perguruan tinggi di DIY. Sebanyak 166 mahasiswa dipilih dengan metode convenience sampling untuk dijadikan sebagai sampel penelitian. Dengan menggunakan analisis regresi dan program SPSS dapat dibuktikan adanya pengaruh tidak langsung kualitas jasa terhadap kesejahteraan subjektif. Hasil penelitian menunjukkan kepuasan dan identifikasi pelanggan-perusahaan mempunyai peranan yang sangat penting, karena kedua variabel berfungsi sebagai mediator dari pengaruh kualitas jasa terhadap kesejahteraan subyektif, tetapi kepuasan mempunyai peran yang lebih dominan dibandingkan identifikasi pelanggan. Dari hasil penelitian tersebut disarankan perguruan tinggi perlu memperhatikan kedekatan hubungan dengan mahasiswanya, namun yang lebih utama adalah meningkatkan kepuasan mereka kepada keseluruhan layanan, seperti ketika berada di lingkungan kampus.
\end{abstract}

Kata kunci- kualitas jasa, kepuasan, identifikasi pelanggan-perusahaan, kesejahteraan subjektif 


\section{INTRODUCTION}

Nowadays education has become an important element in people's lives and has a role to improve the welfare of one's life. One level of education that is considered important at this time is the level of higher education. With increasingly diverse higher education choices, high school students will look for institutions that will provide education that helps them prepare for successful careers and lucrative jobs (Asaduzzaman et al., 2013). Therefore higher education need to pay attention to how they facilitate the needs of consumers (students).

In practice the higher education as an institution that offers educational services certainly needs to pay attention to the quality provided to its students as consumers. The service quality in an educational institution is based on the educational experience gained by students, for example it can be in the form of activities offered, facilities offered, interactions with people in the institution, and contact with institutional staff (Asaduzzaman et al., 2013). It is important for educational institutions to pay attention to the service quality provided in order to be seen well in the eyes of students, so it is hoped that this will also bring benefits to these educational institutions.

Service quality is often associated with customer satisfaction (Albari \& Kartikasari, 2019). Even Su et al. (2016) and Alves \& Raposo (2010) managed to prove the positive influence of service quality on satisfaction. In addition, the importance of the relationship between the two variables can be measured by its role in the subjective well-being of consumers.

Diener et al. (2003) explain that subjective well-being is a scientific analysis of how people judge their quality of life. The assessment is in the form of his emotional reaction about events, moods, their assessment of the form of their life satisfaction and how to fulfill that satisfaction. The opinion of Diener et al. identified the relationship between service quality and satisfaction with the subjective well-being of consumers.

In addition to satisfaction, high service quality can also affect the ability of consumers to identify themselves in accordance with the company's brand image (He \& Li, 2011). Customer-company identification can, among other things, make consumers psychologically bound and concerned with a company (Bhattacharya \& Sen 2003). In the end the level of success of customers who are able to identify themselves with the company can form subjective well-being (Su et al., 2016).

The linkages between the variables mentioned above might also apply to educational institutions, especially at the tertiary level of education, such as higher education. In addition to paying attention to the level of service quality provided according to students' expectations or not, higher education must also be able to create satisfaction with their students or foster a sense of good customer-company identification in themselves. Moreover, these three variables are likely to affect the subjective well-being of these students. The hope is that when higher education have paid attention to the four variables above, they can compete in winning or maintaining the hearts of their consumers (students).

Therefore, this study besides looking at the direct effect of service quality on subjective well-being, also seeks to see the ability of satisfaction and customer-company identification as a mediating variable of the interrelationship of the two variables. Practically the results of the research focus can then be used by higher education and other higher education to emphasize important variables that need to be maintained or improved in order to achieve the level of subjective well-being of customers.

\section{LITERATURE REVIEW}

This section will explain the understanding and interrelationship between the variables of this study, namely about subjective well-being, service quality, satisfaction, and customer-company identification.

\section{A. Subjective Well-being}

Subjective well-being is one's perception and experience of positive and negative emotional responses, and one's specific cognitive evaluation of life satisfaction (Proctor, 2014). Meanwhile according to Diener et al. (2003) subjective well-being is an analysis or self-evaluation of a person's quality of life over time.

Furthermore Diener et al. (2003) explain the evaluation includes a person's emotional reaction to events, moods, and their assessment of the form of satisfaction they want and how to fulfill it. Elwick \& Cannizzaro (2017) agree on the need for emotional well-being, but also the need for psychological well-being through selfacceptance components, positive relationships with others, self-development, goals in life, environmental 
mastery, and autonomy. Therefore, according to Elwick \& Cannizzaro student welfare is also one of the main objectives that need to be considered by higher education, besides satisfaction and loyalty.

The level of subjective well-being can be influenced by various factors, such as satisfaction (Dagger \& Sweeney, 2006; Akbag \& Ummet, 2017; Elwick \& Cannizzaro, 2017); customer-company identification (Mael \& Ashforth, 1992; Su et al., 2016), and service quality (Dagger \& Sweeney, 2006; Su et al., 2016).

\section{B. Service Quality}

Quality can be assessed as a measure used to implement an effective culture (Shabbir et al., 2017). Quality can be used as a basis for an assessment of an entire company or its activities are running properly. In addition to the manufacturing and production industries, quality has also been widely used within the scope of the service industry. Parasuraman et al. (1985) explain that service quality is a tool to measure how well companies provide services to consumers.

Developing the results of previous studies, Parasuraman et al. (1988) explained that service quality can be described as a comparison between consumers' expectations about the services they will receive with the real services they have received. Parasuraman et al. (1988) simplified 10 (ten) dimensions to 5 (five) service quality dimensions known as SERVQUAL, namely the dimensions of reliability, responsiveness, tangible, assurance, and empathy. The first three dimensions (reliability, responsiveness, tangible) correspond to three important aspects of the results of previous studies, while the assurance and empathy dimensions are formed from the seven previous important aspects, namely competence, access, courtesy, communication, credibility, security, and understanding.

Meanwhile Cronin \& Taylor (1992) explain service quality is directly affected by consumers' perceptions of the performance of companies, meaning that service quality is the performance of services provided by companies that consumers really feel. One of the main differences with the research of Parasuraman et al. (1988) is that the research of Parasuraman et al. uses measurements of the appropriateness of quality perceptions with customer expectations to obtain service quality, whereas in Cronin \& Taylor's (1992) research also uses quality measurements using only the level of service quality based on customer perceptions of the performance of the service.

In the scope of education the service quality is not only important, but also a parameter of the quality of education. According to Asaduzzaman et al. (2013) service quality is the key to measuring the quality of education of a higher education, and being the main variable for higher education creates a strong perception in the minds of consumers.

Furthermore, Hutchinson et al. (2009) stated that service quality is an important antecedent for customer satisfaction. Cronin et al. (2000) and Bei \& Chiao (2001) also introduced the concept of the relationship between service quality and service satisfaction. Even Cronin et al. and Bei \& Chiao prove that consumers' expectations about the services they want with the services they get actually affect positively on their satisfaction. Likewise Albari \& Kartikasari (2019) proved the positive influence of service quality on satisfaction. Specifically, Alves \& Raposo (2010) stated that service quality as an important parameter of educational excellence has a positive influence on the satisfaction of a student. Therefore, the hypothesis is:

\section{H1: There is a positive effect on service quality on satisfaction}

Service quality is also often associated with customer-company identification. He \& Li (2011) found that the better the service quality obtained by customers, the stronger the level of identification about the company. While Ahearne et al. (2005) suggest that service quality can also contribute to the development of customercompany identification. Thus the hypothesis formulation is:

\section{H2: There is a positive effect on service quality on customer-company identification}

In a study conducted by Dagger \& Sweeney (2006), perceived service quality not only affects the interest in behavior, but also affects the quality of life of a consumer. The study also explained that the results of evaluations of service quality were subjective well-being. While Su et al. (2016) managed to prove the positive influence of service quality on subjective well-being, so the hypothesis of this study is:

\section{H3: There is a positive effect on service quality on subjective well-being}




\section{Satisfaction}

Satisfaction is the level of feeling happy or disappointed after someone compares the performance of the product / service that is thought to be expected (Kotler \& Keller, 2016). Parasuraman et al. (1988) explain that consumer satisfaction is related to the psychological state of consumers, in assessing the wisdom between what consumers actually get and give. While Oliver (1981) states that satisfaction is the psychological state of a person who appears when the product / service that is obtained is able to meet their needs. Whereas Bei \& Chiao (2001) argue that consumer satisfaction is a condition that is felt by consumers when the performance / service results obtained can meet their expectations.

Buyers of a higher education education are students. Therefore higher education must be able to predict the needs of students. According to Asaduzzaman et al. (2013) for higher education to be able to survive, higher education need to satisfy students by providing the services they need, so that at a time when they wish to continue their education, the higher education remains their first choice.

Satisfaction is also considered to have an impact on the subjective well-being of a consumer. In their research, Dagger \& Sweeney (2006) found that consumer satisfaction has an impact on consumers' perceptions of their quality of life. Though quality of life is a form of subjective well-being of a person (Dagger \& Sweeney, 2006). The results of the study are corroborated by Akbag \& Ummet (2017), which proves that satisfaction of basic psychological needs of students has a positive effect on their subjective well-being, differentiated by gender, courage, autonomy, competence and interrelation. Meanwhile Elwick \& Cannizzaro (2017) explained that when students feel satisfied with the services provided by the higher education, then that satisfaction will affect the happiness and level of welfare felt by students. Therefore, the following hypothesis is determined:

\section{H4: There is a positive effect of satisfaction on subjective well-being}

\section{Customer-Company Identification}

Understanding of customer-company identification departs from social and organizational identification theory (Su et al., 2016). According to Mael \& Ashforth (1992) social identification is the perception of one's ownership of group classifications, that is, actually or symbolically someone considers himself psychologically related to the group's fate, as people who share a common destiny in their successes and failures. While organizational identification is a person's social identification of membership in a particular organization.

Referring to this understanding, Bhattacharya \& Sen (2003) said that customer-company identification is a condition of consumers who have a strong sense of the company that provides products / services to him, so that the company is already considered part of the consumer. Someone has a customer-company identification because the company has important, distinctive and lasting characteristics (Ahearne et al., 2005). The characteristics of customer-company identification, among others, can make consumers psychologically bound and care about a company (Bhattacharya \& Sen, 2003). In the context of a higher education, Mael \& Ashforth (1992) explained that when an alumni works for a company and he has good performance, the alumni indirectly reflects the quality level of his higher education.

The characteristic of customer-company identification is its own advantage, because customer-company identification encourages consumers to establish positive relationships with companies (Mael \& Ashforth, 1992). In return the company must be able to help consumers achieve their own needs and improve their subjective wellbeing (Su et al., 2016). Further, Su et al. succeeded in proving that customer-company identification can positively influence subjective well-being.

With the explanation above, the formulation of the research hypothesis is:

H5: There is a positive effect of customer-company identification on subjective well-being

\section{E. Conceptual Framework}

From the literature review above, a conceptual framework is proposed as shown in Figure 1. 


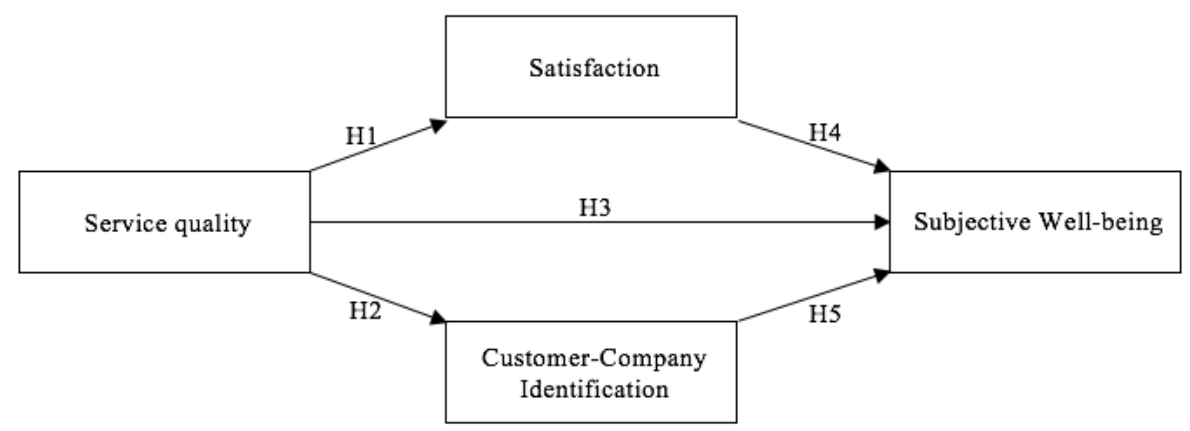

Figure 1: Research Conceptual Framework

Figure 1 shows the interrelationships between the variables described above. Service quality directly (H3) and indirectly has a positive effect on subjective well-being. The indirect effect is mediated by satisfaction (H1 and $\mathrm{H} 4$ ) and customer-company identification (H2 and H5).

\section{RESEARCH METHODS}

This research is a quantitative study using survey and questionnaire methods as research data collection instruments. The research population is students who study at 6 higher education in the Special Region of Yogyakarta (DIY), namely UII, UGM, UPN, UNY, UMY and STIE YKPN. The six colleges are among the largest in DIY. As many as 166 students were included as research samples, which were obtained with the formula Lemeshow et al. (1990) and based on a 99\% confidence level, and a maximum sampling deviation of $10 \%$. Samples of students who are on campus were chosen by the convenience sampling method.

Furthermore, the operationalization of the research variables is determined in Table 1.

Based on the understanding in Table 1, data collection was carried out for 3 weeks using a questionnaire. To obtain instrument eligibility, validity and reliability tests were performed. The validity testing method uses the Pearson correlation formula, with the help of a data processing program SPSS 21.0 and a trial sample of 30 respondents. Meanwhile, to test for acceptable reliability, the Cronbach's Alpha (CA) measurement method is used for a minimum of 0.6 (Sekaran \& Bougie, 2016).

Table 1: Identification of Operational Variables

\begin{tabular}{l} 
Variables / indicators \\
\hline Service quality is the performance of services provided by higher education that are truly felt by students \\
Facilities / physical buildings Higher education is interesting \\
Keep promises to students \\
Responsiveness to student requests \\
Guaranteed environmental conditions \\
Seriously prioritizing the interests of students \\
Satisfaction is a psychological state of students that arises when their needs are met \\
Overall satisfaction with Higher Education \\
Satisfaction with Higher Education services \\
Satisfaction when in Higher Education \\
Customer-company identification is a condition of students who have a strong sense of the higher \\
education that provides education services to him, so that the higher education is already considered part \\
of students.
\end{tabular}

Emotions when Higher Education are criticized.

Want to know people's opinions about Higher Education

Feeling to be a part of Higher Education

Also feel successful when the Higher Education is successful. 
Feeling happy when the Higher Education was praised.

Feelings of shame when the Higher Education was criticized

Subjective well-being is the analysis or self-evaluation of a person's quality of life over time.

Feeling to be someone happy

Feel happier than his colleagues

Feeling you can enjoy life

Source: literature review

The results of testing the validity of the whole statement items produce a probability of 0,000 , or smaller than a very significant level of $1 \%$. While the CA value for service quality is 0.822 , satisfaction $(0.870)$, customercompany identification (0.675), and subjective well-being (0.701). Because all items of statements and research variables are proven to be valid and reliable, the above research instruments can be used to obtain analytical data.

Data collected was analyzed by regression. The regression analysis process is carried out with 3 stages of the standardized regression model, namely as follows:

$$
\begin{array}{lll}
\text { Model-1 regression analysis }: & \text { Sat. }=\beta \mathrm{SQ} \\
\text { Model-1 regression analysis } & : & \mathrm{CCI}=\beta \mathrm{SQ} \\
\text { Model-1 regression analysis } & : & \mathrm{SWB}=\beta 1 \mathrm{SQ}+\beta 2 \text { Sat. + } 33 \mathrm{CCI}
\end{array}
$$

For the validation of the regression calculation six test methods are used, namely the $\mathrm{F}$ and $\mathrm{t}$ tests as well as four classic assumption tests (heteroscedasticity, multicollinearity, normality, and linearity). All of these calculations use the SPSS data processing program version 21.0.

\section{RESULTS AND DISCUSSION}

Before being used for analysis, 166 cases of data obtained were first tested for their validity and reliability. This data quality testing method is the same as testing the validity and reliability of the instrument. The results of testing the quality of the data are listed in Table 2.

The results of the calculations in Table 2 show all the statements to reveal each variable can be obtained the probability of 0,000 or below a very significant level of $1 \%$, or declared valid. The Cronbach's Alpha value for all variables can be obtained far above the critical limit of 0.6 , or set variables. From these results it can be concluded that all statement items and research variables can be used for regression analysis.

Table 2 also explains all statements and research variables assessed by students included in the above average category with a value of $3.41-4.20$, except for the statement of responsiveness to student demand and seriously prioritizing student interests in the service quality variable (3,10 and 3.34) as well as emotional statement items when tertiary college students receive criticism on the customer-company identification variable (3.31).

The next stage of the analysis will be in the form of testing the research hypotheses that have been proposed at the front. The testing process uses regression analysis techniques, both simple (Models-1 and 2) and multiple (Model-3). In addition, a series of tests was carried out to strengthen the results of the regression analysis, namely the F and t tests, the VIF formula (multicollinearity), the Glejser formula (heteroscedasticity), the KolmogorofSmirnof formula (normality), and the Lagrange Multiplier formula (linearity). 
Table 2: Recapitulation of Data Validity and Reliability Tests

\begin{tabular}{|c|c|c|c|}
\hline Variables / indicators & Valid. & Reliab. & Mean \\
\hline Service quality & & 0,909 & 3,50 \\
\hline Facilities / physical buildings Higher education is interesting & 0,000 & & 3,66 \\
\hline Keep promises to students & 0,000 & & 3,53 \\
\hline Responsiveness to student requests & 0,000 & & 3,10 \\
\hline Guaranteed environmental conditions & 0,000 & & 3,85 \\
\hline Seriously prioritizing the interests of students & 0,000 & & 3,34 \\
\hline Satisfaction & & 0,948 & 3,64 \\
\hline Overall satisfaction with Higher Education & 0,000 & & 3,69 \\
\hline Satisfaction with Higher Education services & 0,000 & & 3,52 \\
\hline Satisfaction when in Higher Education & 0,000 & & 3,72 \\
\hline Customer-company identification & & 0,817 & 3,75 \\
\hline Emotions when Higher Education are criticized. & 0,000 & & 3,31 \\
\hline Want to know people's opinions about Higher Education & 0,000 & & 3,78 \\
\hline Feeling to be a part of Higher Education & 0,000 & & 3,72 \\
\hline Also feel successful when the Higher Education is successful & 0,000 & & 3,92 \\
\hline Feeling happy when the Higher Education was praised. & 0,000 & & 3,93 \\
\hline Feelings of shame when the Higher Education was criticized & 0,000 & & 3,86 \\
\hline Subjective well-being & & 0,895 & 3,79 \\
\hline Feeling to be someone happy & 0,000 & & 3,83 \\
\hline Feel happier than his colleagues & 0,000 & & 3,53 \\
\hline Feeling you can enjoy life & 0,000 & & 4,01 \\
\hline
\end{tabular}

The first regression analysis (Model-1) is a simple regression analysis to reveal the positive influence of service quality on satisfaction. The calculation results are shown in Table 3.

Table 3: Regression Model-1 with Satisfaction Dependent Variable

\begin{tabular}{lcccc}
\hline & $\beta$ & $\mathrm{p}-\mathrm{t}$ & Heterosced. (Sig.) & $\mathrm{R}^{2}$ \\
\hline Service quality & 0,726 & 0,000 & 0,413 & 0,524 \\
Normality test & & 0,650 & & \\
Linearity test & & 0,000 & & \\
\hline Source: primary
\end{tabular}

Source: primary data calculation

Table 3 shows the results of the calculated probability (p) of 0,000 or less than the value of 5\%. If referring to the first research hypothesis (H1), it can be proven that there is a positive influence on service quality on satisfaction.

This conclusion is strengthened by the classical assumption test. Table 3 also shows the probability of the Heteroscedasticity test and the Kolmogorov-Smirnov (K-S) test with a calculated probability value of 0.413 and 0.650 , or greater than the $5 \%$ significance level. Thus the regression model is said to be good, because there are no symptoms of Heteroscedasticity but the distribution of data meets the assumption of normality. The X2 value from the Lagrange Multiplier method shows a result of 0,000 or smaller than the X2 table $(197,064)$, so that the use of the Model-1 regression model has fulfilled the linearity assumption.

Based on the results of these tests can also be determined the value of the determinant coefficient (R2) of 0.524 . This means that of all the variables that might affect satisfaction by $52.4 \%$ can be explained by service quality, as in Model-1.

Next, a simple regression analysis of Model-2 with independent service quality variables and the dependent variable is customer-company identification. Table 4 presents a recapitulation of the Model-2 regression calculation results.

Table 4: Regression Model-2 with Customer-Company Identification Dependent Variable 


\begin{tabular}{lcccc}
\hline & $\beta$ & $\mathrm{p}-\mathrm{t}$ & Heterosced. (Sig.) & $\mathrm{R}^{2}$ \\
\hline Service quality & 0,443 & 0,000 & 0,132 & 0,192 \\
Normality test & & 0,665 & & \\
Linearity test & & 0,000 & & \\
\hline Source: prist
\end{tabular}

Source: primary data calculation

The explanation of the calculations presented in Table 4 is relatively the same as the simple regression analysis of Model-1, both the results of the t-test, heteroscedasticity, normality, and linearity testing. All tests show significant results, so it can be concluded that the second hypothesis (H2) which mentions the positive influence of service quality on customer-company identification can be proven very significantly, namely with an effect of $19.2 \%$.

Next is explained in Table 5, which contains the results of calculations in Model-3 regression analysis. The model is used to determine the positive influence of service quality (H3), satisfaction (H4), and customer-company identification (H5) on subjective well-being.

Table 5: Regression Model-3 with Subjective Well-being Dependent Variables

\begin{tabular}{lcc}
\hline & $\beta$ & $\mathrm{p}-\mathrm{t}$ \\
\hline Service quality & $-0,022$ & 0,4055 \\
Satisfaction & 0,406 & 0,000 \\
Customer-company identification & 0,295 & 0,000 \\
p-F & & 0,000 \\
\hline
\end{tabular}

Source: primary data calculation

The summary of calculations in Table 5 shows the value of $\mathrm{p}-\mathrm{F}=0,000$. Because it is stated service quality, customer satisfaction, and customer-company identification have a significant positive effect on subjective wellbeing simultaneously. But when tested partially, it turns out that service quality has a negative beta coefficient and sig-t of 0.4055 or higher than the critical limit of significance of 0.05 . Therefore $\mathrm{H} 3$ must be rejected, meaning that there is no positive influence on service quality on subjective well-being. Meanwhile, because the beta coefficient is positive for customer-company satisfaction and identification and sig-t is smaller $(0,000)$ than $5 \%$, then $\mathrm{H} 4$ and $\mathrm{H} 5$ are rejected, meaning that customer-company satisfaction and identification has a positive influence on subjective well-being. .

Therefore a regression model-3 needs to be modified, which is to prove that customer-company satisfaction and identification really have a positive influence on subjective well-being. The calculation is done by removing the service quality variable from model-3. The results of the modified calculations are presented in Table 6 .

The probability values for the F-test (sig-F) and the t-test (Sig-t) in Table 6 show the results of 0,000 , or less than the critical value (significance) of 5\%, so the research hypotheses (H4 and H5) which state satisfaction and customer-company identification simultaneously or partially has a positive influence on subjective well-being has been proven.

Table 6: Modification of Model-3 Recapitulation with Subjective Well-being Dependent Variables

\begin{tabular}{lccccc}
\hline & $\wp$ & $p-t$ & VIF & Heterosced. (Sig) & $\mathrm{r}^{2}$ \\
\hline Satisfaction & 0,391 & 0,000 & 1,296 & 0,798 & 0,153 \\
Customer-company & 0,292 & 0,000 & 1,296 & 0,667 & 0,092 \\
identification & & & & \\
p-F & & & 0,000 & & \\
Normality test & & 0,215 & & \\
Linearity test & & 0,000 & \\
Adj. R2 & & 0,339 & & \\
\hline
\end{tabular}

Source: primary data calculation

The results of testing classic assumptions can further strengthen the conclusions above. Table 6 also shows the probability of the heteroscedasticity test and the Kolmogorov-Smirnov (K-S) test are 0.413 and 0.650 , both of which are higher than the 5\% significance level. Thus the regression model is said to be good, because there are no symptoms of heteroscedastisitas but the distribution of data meets the assumption of normality. While for multicollinearity testing shown by the VIF value smaller than the critical value 10 , it is said that there are no 
significant correlation symptoms in the customer-company satisfaction and identification variables. The X2 value of the Lagrange Multiplier method shows a result of 0,000 or smaller than the X2 table $(197,064)$, so that the use of the modified Model-3 regression model meets the linearity assumption.

Based on the results of these tests can also be determined the value of the determinant coefficient (R2), both total and partial. The calculation results show $\mathrm{R} 2$ of 0.339 , meaning that of all the variables that might affect subjective well-being, then $33.9 \%$ can be explained by customer-company satisfaction and identification, while the other $66.1 \%$ is not influenced by the variables in the regression The modified Model-3. Meanwhile, if seen from the partial coefficient value, satisfaction accounts for $15.3 \%$ and customer-company identification accounts for $9.2 \%$ of the total that affects subjective well-being.

Based on the calculation of the three regression models above, obtained several results of the analysis that are appropriate or not in accordance with the hypothesis that has been stated before, so that the discussion and implications can be carried out below.

\section{A. Effect of Service Quality on Satisfaction}

The results of the linear regression calculation for model-1 found a positive and significant effect of service quality on satisfaction. This analysis has proven the suitability of the hypothesis (H1) with the empirical results of the study. These results also support the results of research and opinions of Albari \& Kartikasari (2019), Alves \& Raposo (2010), Bei \& Chiao (2001), and Cronin et al. (2000). When combined with descriptive analysis, service quality is a variable that needs special attention by higher education to achieve student satisfaction, especially in the form of a conducive academic environment and atmosphere as well as attractive physical facilities and buildings.

\section{B. Effect of Service Quality on Customer-Company Identification}

From Model-2 it can also be proven that there is a positive and significant influence of service quality on customer-company identification (H2). With these conclusions empirical research from He \& Li (2011) and Ahearne et al. (2005) became supported, so in addition to paying attention to the influence of service quality variables on satisfaction, higher education also need to pay attention to the customer-company identification of their students.

\section{Effect of Service Quality, Satisfaction, Customer-Company Identification on Subjective Well-being}

The results of Model-3 have two calculations. In the first calculation, it is concluded that there is a negative and insignificant influence on service quality on subjective well-being, while customer-company satisfaction and identification have succeeded in positively influencing subjective well-being. If it is related to descriptive analysis, it is possible that the negative influence of service quality is due to the low contribution of indicators that are directly related to the interests of students (responsiveness of student demand and seriously prioritizing the interests of students), while subjective well-being indicators are always valued at a high average. This possibility is reasonable, because the indicator points on customer-company satisfaction and identification are more aligned with subjective well-being than service quality variables. The second possibility is that, on average, the value of service quality and subjective well-being has a tendency that is not the opposite, if the average service quality is low, subjective well-being tends to be high, and vice versa. This condition is likely to cause service quality to be a negative and not significant effect on subjective well-being.

The results of the modification of the Model-3 regression showed satisfaction and customer-company identification proved to have a positive and significant effect on subjective well-being. From these conclusions, hypotheses H4 and H5 can be supported / proven. These results also reinforce the results of empirical research from Elwick \& Cannizzaro (2017), Akbag \& Ummet (2017), and Dagger \& Sweeney (2006), as well as research by Su et al. (2016) and Mael \& Ashforth (1992).

Furthermore, from the modification of Model-3 it can also be seen that satisfaction has a greater contribution than the customer-company identification of the subjective well-being of students. This shows that satisfaction has a more important role to be obtained by students in real contributing to their subjective well-being, compared 
to waiting for the reaction or assessment of others in identifying customer-company. Therefore higher education need to pay attention to efforts to always maintain or increase student satisfaction, especially when students are on the college campus.

The results of this analysis also prove that consumer satisfaction and company-customer identification are dominant variables in the entire research model, because only with these two variables can service quality affect the subjective well-being of students, that is, as a full mediator variable. These conditions support the research of $\mathrm{Su}$ et al. (2016). In other words, the service quality provided by higher education will basically affect the way students think about quality of life and happiness (subjective well-being). However, the influence exerted was not immediate, but had to pass through a sense of satisfaction and a sense of attachment to the higher education (customer-company identification).

From the overall results of the analysis that has been done there are several things that need to be considered by higher education. Higher education need to improve and maintain the quality of their services. When the service quality provided is good / good students tend to feel satisfied and proud to be at the college. It will affect their quality of life, where they will tend to feel happy.

Companies engaged in services, of course need to think about how consumers feel when they get the service. Service companies should not only think profit oriented, they also need to think of more social outcomes such as the happiness of consumers when using company services. Because subjective well-being itself is a relevant outcome considered in consumers' use of services.

\section{CONCLUSIONS AND RECOMMENDATIONS}

From the explanation above, it can be concluded that the research hypotheses are proven, except there is a positive direct effect of service quality on subjective well-being. The effect of service quality is only able to affect welfare, if through mediator variable satisfaction and customer-company identification. As a mediator variable, the results of the study also showed that satisfaction has a stronger / more dominant role than customer-company identification.

There are three implications from the conclusion above. First, higher education need to improve and maintain the quality of their services. When the service quality provided is good / good students tend to feel satisfied and proud to be at the college. It will affect their quality of life, where they will tend to feel happy.

Second, the research model can also be used to conduct research in other service companies. Service companies certainly need to think about how their customers feel when they get the service. Service companies can not only be profit-oriented, but they also need to think of results that are more social in nature, such as the happiness of consumers when using company services. Because subjective well-being itself is a relevant outcome considered in consumers' use of services.

Third, research models with subjective well-being variables are still relatively limited in number. Therefore, in addition to this research, it can enrich the discussion about research with similar variables, future research needs to be considered to involve variables that may be relevant and have not been included in this research model, such as trust, commitment, or customer loyalty 


\section{REFERENCES}

Albari, \& Kartikasari, A. (2019). The influence of product quality, service quality and price on customer satisfaction and loyalty. AJEFB-Asian Journal of Entrepreneurship and Family Business, 3(1), 49-64.

Ahearne, M., Bhattacharya, C. B., \& Gruen, T. (2005). Antecedents and consequences of customer-company identification: expanding the role of relationship marketing. Journal of Applied Psychology, 90(3), 574585.

Akbag, M., \& Ummet, D. (2017). Predictive role of grit and basic psychological needs satisfaction on subjective well-being for young adults. Journal of Education and Practice, 8(26), 127-135.

Alves, H., \& Raposo M. (2010). The influence of university image on students behavior. International Journal of Educational Management, 24(1), 73-85.

Asaduzzaman, Hossain. M., \& Rahman. M. (2013). Service quality and student satisfaction: a case study on private universities in Bangladesh. International Journal of Economics, Finance and Management Sciences, 1(3), 128-135.

Bei, L. T., \& Chiao, Y. C. (2001). An integrated model for the effects of perceived product, perceived service quality, and perceived price fairness on consumer satisfaction and loyalty. Journal of Consumer Satisfaction, Dissatisfaction and Complaining Behavior, 14, 125-140.

Bhattacharya, C. B., \& Sen. S. (2003). Consumer-company identification: a framework for understanding consumers' relationships with companies. Journal of Marketing, 67(April), 76-88.

Cronin, J. J., \& Taylor, S. A. (1992). Measuring service quality: a re-examination and extension. Journal of Marketing, 56(3), 55-68.

Cronin, J. J., Jr., Brady, M. K., \& Hult, G. T. M. (2000). Assessing the effects of quality, value, and customer satisfaction on consumer behavioral intentions in service environments. Journal of Retailing, 76(2), 193218.

Dagger, T., \& Sweeney, J. C. (2006). The effect of service evaluations on behavioral intentions and quality of life. Journal of Service Research, 9(1), 3-18.

Diener, E., Oishi, S., \& Lucas, R. E. (2003). Personality, culture, and subjective well-being: emotional and cognitive evaluations of life. Annual Review of Psychology, 54, 403-25.

Elwick, A., \& Cannizzaro, S. (2017). Happiness in higher education. Higher Education Quarterly, First published(19 March), 1-16. https://doi.org/10.1111/hequ.12121.

He, H., \& Li, Y. (2011). CSR and service brand: the mediating effect of brand identification and moderating effect of service quality. Journal of Business Ethics, 100(4), 673-688.

Hutchinson, J., Lai, F., \& Wang, Y. (2009). Understanding the relationship of quality, value, equity, satisfaction, and behavioral intentions among golf travelers. Tourism Management, 30(2), 298-308.

Kotler, P., \& Keller, K. L. (2016). Marketing management. (15th ed.). Pearson Prentice Hall.

Lemeshow, S., Hosmer Jr, D. W., Klar, J. \& Lwanga, S. K. (1990). Adequacy of sample size in health studies. John Wiley \& Sons Ltd.

Lyubomirsky, S., \& Lepper, H. S. (1999). A measure of subjective happiness: preliminary reliability and construct validation. Social Indicators Research, 46(2), 137-155.

Mael, F., \& Ashforth, B. E. (1992). Alumni and their alma mater: a partial test of the reformulated model of organization identification. Journal of Organizational Behavior, 13(2), 103-123.

Maxham III, J. G., \& Netemeyer, R. G. (2002). A longitudinal study of complaining customers' evaluations of multiple service failures and recovery efforts. Journal of Marketing, 66(4), 57-71.

Parasuraman, A., Zeithaml, V., \& Berry, L. L. (1985). A conceptual model of service quality and its implications for future research. Journal of Marketing, 49(4), 41-50.

Parasuraman, A., Zeithaml, V. A., \& Berry, L. L. (1988). SERVQUAL: a multiple-item scale for measuring consumer perceptions of service quality. Journal of Retailing, 64(1), 12-40.

Proctor, C. (2014). Subjective well-being (SWB). Encyclopedia of quality of life and well-being research, 64376441.

Sekaran, U., \& Bougie, R. (2016). Research method for business: a skill building approach (7th ed.). John Wiley dan Sons Ltd.

Shabbir, A., Malik, S. A., \& Janjua, S. Y. (2017). Equating the expected and perceived service quality a comparison between public and private healthcare service providers. International Journal of Quality \& Reliability Management, 34(8), 1295-1317. 
Su, L., Swanson. S.R., \& Chen. X. (2016). The effects of perceived service quality on repurchase intentions and subjective well-being of Chinese tourists: the mediating role of relationship quality. Tourism Management, 52, 82-95. 